\title{
Lymphocytic choriomeningitis virus: invisible but not innocent
}

\author{
K. LAPOŠOVÁ, S. PASTOREKOVÁ, J. TOMÁŠKOVÁ*
}

Department of Molecular Medicine, Institute of Virology, Slovak Academy of Sciences, Dúbravská cesta 9, 84505 Bratislava, Slovak Republic

\begin{abstract}
Summary. - Lymphocytic choriomeningitis virus (LCMV) attracts significant attention both as an important experimental model system to study acute and persistent viral infections, and as a neglected human pathogen of clinical significance. This review focuses on the basic aspects and recent advances in the molecular and cell biology of LCMV, the outcome of LCMV infection on its natural host with an emphasis on persistent infection and the outcome of LCMV infection in humans. Lastly, we summarize our contribution to current knowledge on LCM virus.
\end{abstract}

Keywords: lymphocytic choriomeningitis virus; LCMV infection; persistent infection; MX strain

\section{Contents:}

1. Introduction

2. LCMV life cycle

3. Persistent LCMV infection

4. LCMV infection in humans

5. LCMV MX strain and our contribution to the knowledge of LCMV

\section{Introduction}

Lymphocytic choriomeningitis virus (LCMV) is an often unrecognized cause of sporadic or epidemic, acquired or congenital infections in humans. This prototypic member of the Arenaviridae family was discovered in 1933 by Armstrong and colleagues during the study of samples from a St.

*Corresponding author. E-mail: jana.tomaskova@savba.sk; phone: +421-2-50932439.

Abbreviations: agRNA = antigenome RNA; $a-D G=$ alpha-dystroglycan; DIP = defective interfering particles; ESCRT = endosomal sorting complex required for transport; GP = glycoprotein; $\mathrm{GPC}=$ glycoprotein precursor; IGR = intergenic region; IL-10 = interleukin 10; K1 = keratin 1; LAG-3 = lymphocyte-activation protein 3 ; LCMV = lymphocytic choriomeningitis virus; $\mathrm{MHC}=$ major histocompatibility complex; $\mathrm{NP}=$ nucleoprotein; $\mathrm{PD}-1$ = programmed death-1; RNP = ribonucleoprotein; SSP = stable signal peptide; TIM-3 = T cell Ig- and mucin-domain-containing molecule 3; $\mathrm{VHF}=$ viral hemorrhagic fever
Louis encephalitis epidemic (Armstrong and Lillie, 1934). It was soon found to be a cause of aseptic meningitis (Rivers and Scott, 1935) and to be identical to a pathogen that chronically infected mouse colonies (Traub, 1936). By the 1960s, several other viruses had been discovered that shared common morphology, serology, and biochemical features. These findings led to the establishment of the new virus family Arenaviridae in 1970 (Rowe et al., 1970). According to the current Virus Taxonomy List by the International Committee on Taxonomy of Viruses, Arenaviridae family contains a unique genus Arenavirus that includes 24 species. Based on serological, phylogenetic and geographical data, arenaviruses are divided into two major subgroups, the Old World arenaviruses found in Europe and Africa and New World arenaviruses endemic in the Americas (Clegg, 2002; Charrel et al., 2008). Several arenaviruses, mainly Lassa virus, are causative agents of severe viral hemorrhagic fevers (VHF) in humans associated with significant mortality and high morbidity.

On the other hand, studies on the prototypic arenavirus LCMV have led to major advances in virology and immunology which universally apply to other microbial and viral infections in humans. Investigations using the LCMV model have uncovered much of our current knowledge of viral pathogenesis, viral persistence and other areas of immunobiology including: major histocompatibility complex (MHC) restriction in T cell recognition, immunological tolerance, CD8 and CD4 T cell activity and their roles in viral clearance and immunopathology, T cell exhaustion, $\mathrm{T}$ and $\mathrm{B}$ cell-mediated immune memory, im- 
munocomplex disease and the ability of non-cytolytic persistent riboviruses to avoid elimination by the host immune responses, and to induce disease by interfering with specialized functions of infected cells (Borrow and Oldstone, 1997; Buchmeier and Zajac, 1999; Welsh, 2000; Zinkernagel and Doherty, 1977). These findings raise the possibility of a viral involvement in a variety of human diseases of unknown etiology. Moreover, there is increasing evidence that LCMV is a neglected human pathogen with significant clinical implications.

\section{LCMV life cycle}

Like other arenaviruses, LCMV is enveloped negativestrand RNA virus with a bisegmented genome and life cycle restricted to the cell cytoplasm. Virions are spherical to pleomorphic, ranging in size from 40 to $200 \mathrm{~nm}$ (mean 90-110 $\mathrm{nm}$ ), with a dense lipid envelope and a surface layer covered by equally spaced characteristic spike-like surface structures representing the viral glycoprotein (GP) (Buchmeier et al., 2007). High-resolution cryo-EM studies revealed that the structure of arenavirus particles is highly organized. The surface glycoproteins are aligned with subjacent $\mathrm{Z}$ protein and viral ribonucleoproteins packed into a two-dimensional lattice at the inner surface of the viral membrane (Neuman et al., 2005) (Fig. 1).

The genome consists of small (S, ca $3.5 \mathrm{~kb}$ ) and large (L, ca $7.2 \mathrm{~kb}$ ) RNA segments. Each genomic segment uses an ambisense coding strategy to direct the synthesis of two polypeptides in opposite orientation, separated by a noncoding intergenic region (IGR), composed of a sequence predicted to form a stable hairpin structure (Buchmeier et al., 2007). The S RNA encodes the viral nucleoprotein (NP, ca $63 \mathrm{kDa}$ ) and glycoprotein precursor (GPC, ca $75 \mathrm{kDa}$ ), whereas the L RNA encodes the viral RNA dependent RNA polymerase (RdRp, or L protein) (ca $200 \mathrm{kDa}$ ) and a small RING finger-containing Z protein (ca $11 \mathrm{kDa}$ ) (Fig. 2).

The ambisense organization means that while NP and $\mathrm{L}$ coding regions are transcribed into a genomic complementary mRNA, the GPC and $\mathrm{Z}$ coding regions are translated from the genomic sense mRNAs that are transcribed using the corresponding antigenome RNA (agRNA) species as templates which also function as replicative intermediates (Welsh, 2008) (Fig. 3).

LCMV binding to a cellular receptor and its entry into the cell are initiated by the virus envelope glycoprotein. Post-translational proteolytic processing of GPC generates three components that form the GP complex: the stable signal peptide (SSP, 58aa), GP1 (40-46 kDa), and GP2 (35 kDa). Upon cleavage by cellular signal peptidase in endoplasmic reticulum, GPC is further processed by the cellular proprotein convertase SKI-1/ S1P (subtilisin kexin isozyme-1/site-1 protease) into the GP1 and GP2 subunits (Beyer et al., 2003; Kunz et al., 2003). The

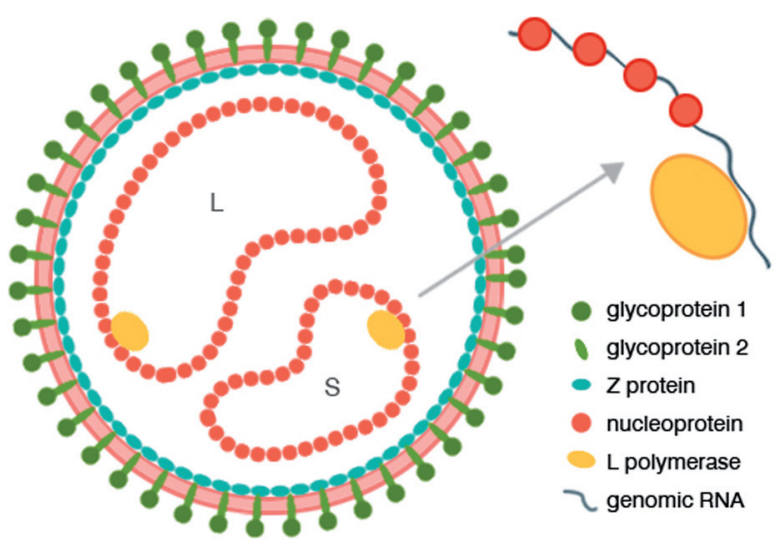

Fig. 1

\section{Structure of LCMV}

LCMV virions are enveloped with a dense lipid envelope. Surface is covered by glycoproteins, which are aligned with Z protein. Viral ribonucleoproteins are packed into two circular structures and are associated with RNA dependent RNA polymerase (L polymerase).

arenavirus SSP is unique in that it remains stably associated with the GP complex, and plays crucial roles not only in the trafficking of GP through the secretory pathway (Eichler et al., 2004; Eichler et al., 2003; York et al., 2004), but also in particle formation and GP-mediated cell fusion (Saunders et al., 2007; York and Nunberg, 2006). GP1 is associated with ionic interaction with GP2, and homotrimer of GP1/GP2 forms the viral spikes that decorate the viral surface (Eschli et al., 2006). GP1 is the virion attachment protein that mediates virus interaction with host cell surface receptors and is located at the top of the spike. GP2 is the transmembrane protein that anchors GP1 to the virus surface. The cellular receptor for LCMV is alphadystroglycan ( $\alpha-D G)$, highly conserved and widely expressed cell surface receptor for proteins of the extracellular matrix (Cao et al., 1998). Upon receptor binding, LCMV virions are taken up in smooth-walled vesicles that are not associated with clathrin and are delivered to acidified endosomes where the viral ribonucleoprotein (RNP) enters the host cell's cytoplasm by a $\mathrm{pH}$-dependent membrane fusion step (Borrow and Oldstone, 1994). The acidic environment of the late endosomes is thought to trigger conformational changes in the GP2 that result in exposure of a fusion peptide that can mediate fusion between virion and host cell membrane (Di Simone and Buchmeier, 1995; Di Simone et al., 1994). Detailed characterization of LCMV entry revealed that virus enters cells predominantly via unusual endocytotic pathway that shows some dependence on membrane cholesterol (Rojek et al., 2008), is independent of clathrin and caveolin, and does not require dynamin, ARF6, flotillin, or actin (Kunz, 2009; Quirin et al., 2008; Rojek et al., 2008). Productive infection with LCMV is dependent on phosphatidyl inositol 3-kinase as well as lysobiphosphatidic acid, an unusual phospholipid 


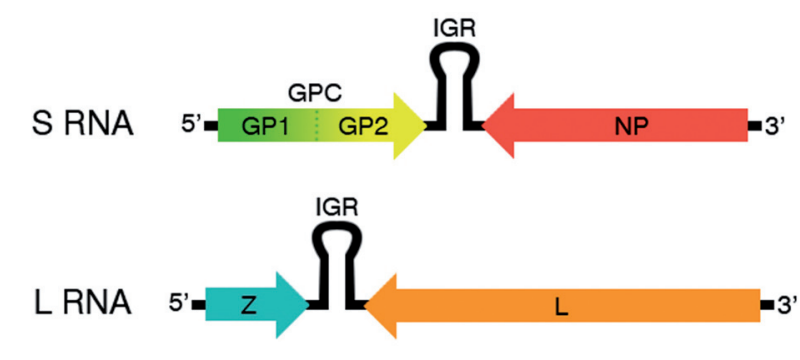

Fig. 2

LCMV encodes two single-stranded RNA segments S and L. Each encodes two proteins in opposite orientation separated by an intergenic region. Short segment S encodes glycoprotein precursor post-translationally cleavaged into GP1 and GP2 and nucleoprotein. Large segment L encodes Z protein and L polymerase.

that is involved in the formation of intraluminal vesicles of the multivesicular body of the late endosome. Moreover, experimental data has shown a role of the endosomal sorting complex required for transport (ESCRT) in LCMV cell entry, in particular the ESCRT components Hrs, Tsg101, Vps22, and Vps24 as well as the ESCRT-associated ATPase Vps4 and Alix (Pasqual et al., 2011).

Once the virus RNP is delivered into the cytoplasm of the infected cell, it serves as a template for both transcription and replication, mediated by the polymerase of LCMV. The activity of the genomic promoter recognized by virus polymerase requires both sequence specificity within the highly conserved 3'-terminal genomes, and the integrity of the predicted panhandle structure formed via sequence complementarity between the 5 '-and 3 '-termini of viral genome RNAs (Perez and de la Torre, 2003). The viral NP and $\mathrm{L}$ proteins are necessary and sufficient for efficient RNA synthesis, both transcription and replication (Lee et al., 2000). Primary transcription initiated at the genome promoters located at each 3 '-end of the RNA segments results in synthesis of NP an L mRNA, respectively. The virus polymerase can subsequently adopt a replicase mode and moves along the IGR to generate a copy of the uncapped full-length agRNA. This agRNA is encapsidated by the NP and serves as a template for the synthesis of the GPC and $\mathrm{Z}$ mRNA as well as for amplification of the corresponding genome RNA species (Perez and de la Torre, 2003). Transcription termination of subgenomic non-polyadenylated viral mRNAs has been mapped to multiple sites within the distal side of the IGR (Meyer and Southern, 1994; Tortorici et al., 2001), suggesting that IGR acts as a transcription termination signal for the virus polymerase. The LCMV mRNAs contain 1-5 non-templated nucleotide(s) of heterogeneous sequence and the cap structure at their 5 '-end (Meyer and Southern, 1993) which are likely obtained from cellular

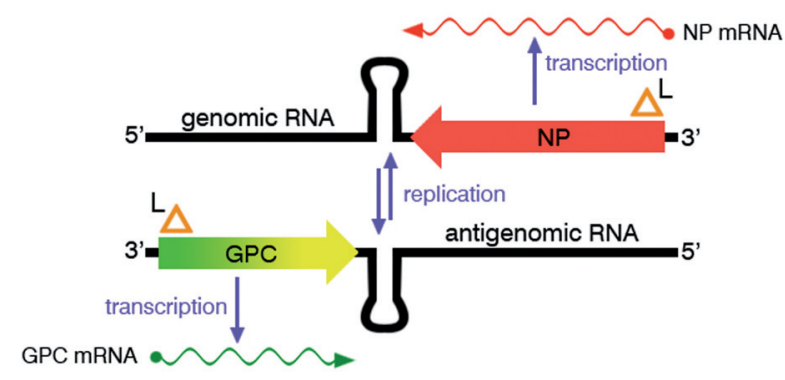

Fig. 3

Replication and transcription of S segment

Ambisense coding strategy of replication means that while NP is transcribed by L polymerase into a genomic complementary RNA, GPC region is transcribed from full length antigenomic RNA. This antigenomic RNA also serves as a template for replication of viral genome.

mRNAs via cap-snatching mechanisms. The exact mechanism of snatching the cap structure is not elucidated. A recently described unique cap-binding feature of LASV NP (Qi et al., 2010) and/or endonuclease activity of the N-terminal domain of the arenavirus L polymerase (Morin et al., 2010) could play a critical role in this process.

The formation and release of LCMV infectious progeny from infected cells requires assembled viral RNPs associated at the cell surface with membranes that are enriched with mature viral GP. The key factor in the budding process is the RING-finger $\mathrm{Z}$ protein that functions as a matrix protein in arenavirus particle assembly (Perez et al., 2003; Strecker et al., 2003). The budding process is mediated by the $\mathrm{Z}$ prolinerich late domain motifs PTAP and PPPY (Freed, 2002) and strictly depends on $\mathrm{Z}$ myristoylation (Perez et al., 2004). LCMV Z protein recruits to the plasma membrane Tsg101, which is a component of the ESCRT-I. Targeting of Tsg101 by RNA interference causes a strong reduction in Z-mediated budding, suggesting that Tsg101 plays a fundamental role in arenavirus budding. Additional cellular proteins are likely to contribute to arenavirus budding (Perez et al., 2003). Incorporation of GPs into virion particles depends on the interaction of GP with Z (Capul et al., 2007). Although an unprocessed GPC can traffic to the cell surface, the correct proteolytical processing of GPC is essential for its incorporation into virions and for the production of infectious virus particles (Burri et al., 2012; Kunz et al., 2003).

\section{Persistent LCMV infection}

The study of LCMV in its natural rodent host has yielded insights into basic understanding of immunological mechanisms that are involved in the establishment and maintenance of persistent viral infection (Zinkernagel, 


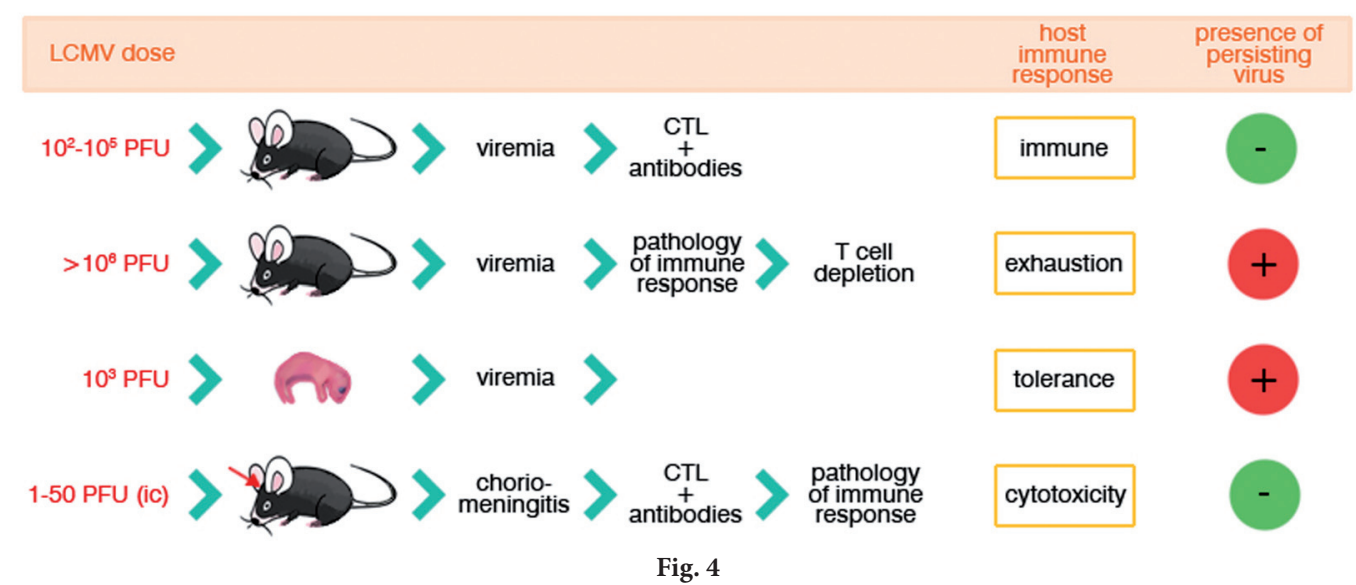

Model of different states of anti-LCMV immunity

According to dose, mouse age and the method of inoculation, LCMV cause different states of anti-LCMV immune responses. ic = intracerebral inoculation; PFU = plaque forming unit; CTL = cytotoxic T cells.

1996). Furthermore, most of these conclusions that were initially defined in LCMV model have since been extended to a variety of persistent human infections including HIV, HCV or HBV (Boni et al., 2007; Urbani et al., 2006; Wilson and Brooks, 2010).

Generally, two conditions are essential for the establishment of persistent virus infection. The first is a unique strategy of viral replication. This means that instead of killing its host cell, the virus causes little or no damage and so continues to reside in those cells. The second requirement is that a host's immune response fails to form or fails to eliminate virus-infected cells, which viruses achieve by application of numerous escape strategies. Viruses can alter or interfere with the processing of viral peptides by professional antigen-presenting cells, downregulate co-stimulatory and/ or MHC molecules required for T cell signaling and expansion or they can disrupt the processing or migration of viral peptides or viral peptide/MHC complexes to cell surfaces (Oldstone, 2009).

LCMV can establish different states of antiviral immunity depending on the virus inoculums and the age of an infected mouse. In general, infection with $10^{2}-10^{5} \mathrm{LCMV}$ virions results in systemic infection of all organs apart from the brain. Massive CD8+ T cell expansion emerges during this infection and significant, albeit less expansion of CD4+ T cells. At around the 7 th day of infection antibodies are detected, but they have no ability to neutralize the virus. Pathogen is completely cleared within 14 days. With larger infection doses (more than $10^{6}$ virions) persistent infection associated with $\mathrm{T}$ cell exhaustion occurs in immunocompetent mice. Persistent infection also emerges after injecting $10^{3}$ virions into newborn mice, which become viremic but have no manifestations of illness. 1-50 virions directly inoculated intracerebrally to adult mice causes choriomeningitis and death within 7-9 days (Fig. 4) (Oldstone, 2002; Zinkernagel, 2002).

LCMV strains which can cause persistent infections (such as DOCILE, CL-13 Armstrong, or Traub) are also marked as CTL-P+, because they cause generalized immunosuppression characterized by $\mathrm{T}$ cell dysfunction and loss of virus specific T cells (Ng et al., 2011). This phenomenon was first described by Zinkernagel's group who observed that the development of long-term LCMV infection was connected with such complete induction of specific antiviral CD8+ cytotoxic T cells that all of them vanished over a few days. Thus the immunity can neither erase the infection nor cause lethal immunopathological disease (Moskophidis et al., 1993). These antigen specific CD8+ cells initially acquire effector functions, but become progressively less functional as the infection develops. They also decline in number (Blackburn et al., 2009). Such a phenomenon was termed "exhaustion" and is now defined as a reduced ability (or inability) of anti-viral T cells to produce certain cytokines and effector molecules (Mueller and Ahmed, 2009). These cells express a unique transcriptional profile causing reduced proliferative capacity, downregulation of $\mathrm{T}$ cell receptor signaling molecules, increased expression of inhibitory surface molecules, losing the ability to produce multiple immunostimulatory and anti-viral cytokines such as interleukin 2, tumor necrosis factor- $\alpha$ and interferon- $\gamma$ (McGavern, 2009; Wilson and Brooks, 2010). Persistent infections of CTL-P+ LCM viruses are also characterized by reduced antibody responses that are ultimately ineffective at clearing virus (Wilson and Brooks, 2010) and by forming infectious virus-antibody immune complexes which sustain persistence and redirect the infection to insusceptible cells without receptors for the virus but with 
expression of $\mathrm{Fc}, \mathrm{C} 1$ or $\mathrm{C} 3$ receptor molecules (Oldstone, 2006). These virus-antibody complexes deposit primarily in the glomeruli of kidneys, blood vessels, and choroid plexus and can cause tissue injury (Oldstone, 2009).

Persistent infections of LCMV are also characterized by decreased accumulation of viral glycoproteins at the surface of infected cells and reduced replication. Also, LCMVspecific defective interfering particles (DIP) containing viral genomes incapable of independent replication arise very soon after the initiation of infection. Truncated genomic RNAs incorporated into DIP may have short deletions at the termini of both S and L RNAs. DI particles may also lack one or both genomic RNAs, GP-1 and GP-2 can be missing or non-glycosylated, and GPC and NP are often altered in size. DI particles can replicate, but fail to transcribe (Francis and Southern, 1988; Meyer and Southern, 1997). In 2008, our study of persistent infection of LCMV strain MX revealed a GPC-carrying RNA subpopulation with a large deletion in the central part of the GPC gene that corresponds to the major subgenomic S RNA of $2.5 \mathrm{~kb}$ which may contribute to MX persistence (Tomaskova et al., 2008). There is also another described phenomenon linked with persistence and glycoprotein. An analysis of the sequences of over 50 viral isolates revealed that CTL-P+ strains (including $\mathrm{Cl} 13$ or MX) usually include a single amino acid change (predominantly leucine, but occasionally isoleucine or valine) at position 260 of the GP1 protein (Sullivan et al., 2011). Moreover, some studies have shown that GP1 residue 260 is required for strong affinity to the $\alpha-D G$ receptor on dendritic cells that help to initiate virus-induced immunosuppression. It is caused by the ability to displace a laminin from the heavily glycosylated region of the $\mathrm{a}-\mathrm{DG}$ of target cells. Conversely, CTL+P- viruses such as Armstrong 53b have a weak affinity to $\alpha-D G$ and encode a phenylalanine at that position ( $\mathrm{Ng}$ et al., 2011; Oldstone and Campbell, 2011).

Dendritic cells are the major antigen-presenting cells responsible for bridging the adaptive and innate immune response and inducing the effective $\mathrm{T}$ cell response, so disruption of its functions leads to decreased $\mathrm{T}$ cell activation and the escape of virus from immune response. Viruses can destroy DCs functions in a variety of mechanisms including downregulation of MHC and co-stimulatory molecules, downregulation of inflammatory cytokines, upregulation of anti-inflammatory cytokines and production of immunosuppressive cytokines. Negative immune regulators include interleukin 10 (IL-10), programmed death 1 (PD-1), T cell Ig- and mucin-domain-containing molecule 3 (TIM-3) and lymphocyte-activation protein 3 (LAG-3) (Ng et al., 2011). In 2006 Ejrnaes and Brooks group in parallel reported that antigen presenting cells in mice persistently infected with LCMV significantly upregulated IL-10 which plays a major role in $\mathrm{T}$ cell exhaustion. However, in vivo blockade of the IL-10 receptor with a neutralizing antibody results in rapid suppression of the persistent infection and restoration of $\mathrm{T}$ cell function (Brooks et al., 2006; Ejrnaes et al., 2006). But the specific mechanisms of IL-10 influence on immune cells are still unclear to this day. Another key signaling pathway operates through PD-1. Barber et al. showed that inhibitory receptor PD-1 (an inhibitory member of the CD28 costimulatory family of molecules) is selectively upregulated on exhausted CD8+ T cells in persistent LCMV infection and that in vivo blockade of PD-1 linkage on its ligand (PD-L1) re-established $\mathrm{T}$ cell function, decreased virus replication and accelerated viral clearance (Barber et al., 2006). TIM-3 is well known as a negative immune regulator and it has been shown that its co-expression with PD-1 was associated with more severe $\mathrm{T}$ cell exhaustion during chronic LCMV infection. Although blockade of TIM-3 does not improve viral control, simultaneous blockade of this regulator and PD-1 significantly improves CD8+ T cell functions (Jin et al., 2010). LAG-3 appears to function similarly to TIM-3, but is suggested to be dependent on PD-1 pathway (Richter et al., 2010).

For a clearance of persistent LCMV infection CD4+ T cells are required which help to assist CD8+ T cells. It has recently been proven that interleukin 21 produced by CD $4+$ T cells directly influences the generation of functional CD8+ $\mathrm{T}$ cells, regulates their exhaustion and is therefore essential for controlling chronic infection (Yi et al., 2009).

Although research on LCMV has led to many insights on viral persistence, significant questions still remain to be answered. Our attention should focus to the delicate balance governing virus-host interaction, since small differences in either viral or host genes seem to enormously influence the course of infection and following disease state.

\section{LCMV infection in humans}

The natural rodent host and reservoir for LCMV are Mus musculus and Mus domesticus, the common house mouse species which are distributed worldwide. The virus is transferred vertically from one generation to the next within the mouse population by intrauterine infection. Mice infected in utero fail to mount an immune response and develop chronic, asymptomatic, life-long infection. Throughout their lives, they shed the virus in large quantities in nasal secretions, saliva, milk, semen, urine, and feces (Childs and Peters, 1993).

Humans can be infected through mucosal exposure to aerosols, or direct contact with rodents, contact with material contaminated with rodent excreta, or through rodent bites. Apart from mice, pet mice and hamsters, as well as experimentally-infected rodents utilized in research have been identified as further sources of infection (Buchmeier and Zajac, 1999; Dykewicz et al., 1992; Emonet et al., 2007). Person 
to person infection has not been described, with exception of transmission through solid-organ transplantation (CDC, 2005; Fischer et al., 2006; MacNeil et al., 2012; Palacios et al., 2008) and vertical transmission from mother to fetus.

Evidence shows the highly focal nature of LCMV and the potential for human illness from exposure to the virus (Foster et al., 2006). The current incidence of clinically significant LCMV infection among humans is unknown. Serologic studies in the USA have revealed that the prevalence of LCMVspecific antibodies among humans is approximately $5 \%$ with a decreasing tendency (Childs et al., 1991, 1992; Park et al., 1997; Stephensen et al., 1992). A seropositivity rate of $4 \%$ for LCMV from human serum samples was noted in Nova Scotia (Marrie and Saron, 1998). In an urban location in Argentina, the prevalence of LCMV antibodies was $1 \%$ to $3.6 \%$ between 1998 and 2003 among humans and 12.9\% among house mice (Riera et al., 2005). In Germany, rates were found in rural residents of the north of $9.1 \%$ and $1.2 \%$ in the south, where the prevalence among mice was also shown to be less common (Ackermann, 1973). The reported LCMV prevalence rates in a 2003 study from Spain were 1.7\% in humans and 9\% in wild rodents (Lledo et al., 2003). Antibodies against LCMV were found in $2.5 \%$ of the serum samples of forestry workers and in $5.6 \%$ of rodents tested in Italy (Kallio-Kokko et al., 2006). In contrast, in our previous study, we found $37.5 \%$ prevalence of anti-LCMV antibodies in human sera from Bratislava in Slovakia (Reiserova et al., 1999). Also Dobec et al (2006) reported 36\% prevalence in Croatia.

Although serosurveys have been conducted on wild mice populations, little is known about the prevalence of LCMV among household pets and laboratory rodents. LCMVinfected pet hamsters can maintain virus transmission without obvious evidence of infection. Several outbreaks of LCMV infection in humans have been linked to exposure to persistently infected hamsters or tumor lines contaminated with LCMV. The largest outbreak of LCMV occurred in 1973-1974 and resulted in 181 human cases in 12 states. This outbreak was associated with pet hamsters supplied by a single distributor (Gregg, 1975; Hotchin et al., 1974). The possible source of LCMV in a transplant-associated outbreak in 2005 was also determined to be a pet hamster (CDC, 2005). Although wild house mice are the natural reservoir for the virus, hamsters and other pet rodents can acquire the virus through exposure to infected mice and become an important source of human exposure.

In immunocompetent individuals, LCMV infections are often asymptomatic or result in a mild self-limiting illness. Symptoms appear 1-3 weeks after exposure and include fever, chills, nausea, vomiting, myalgia, and headache (Buchmeier et al., 2007). In most cases, the disease resolves without treatment within a few days. In a minority of patients, illness can progress to aseptic meningitis or meningoencephalitis. Rarely, meningitis occurs without a prodromal syndrome. Other reported neurological complications associated with LCMV infections in adults are transverse myelitis, Guillain-Barre-type syndrome, hydrocephalus and sensorineural hearing loss (Kunz and de la Torre, 2008). Uncommon non-neurological manifestations of illness include pancreatitis, orchitis, arthritis, parotitis, and pericarditis (Jamieson et al., 2006). In most cases of LCMV infection in adult humans, patients fully recover and fatalities are rare. Although recovery is generally complete, it may require months to achieve.

However, some rare cases show a radically different course of disease that resembles viral hemorrhagic fever caused by the highly pathogenic Lassa virus (Buchmeier et al., 2007). The same pathogenetic process was also observed in three lymphoma patients inoculated with LCMV in an attempt to induce the regression of their tumors refractory to chemotherapy (Horton et al., 1971). These cases were remarkably similar to fatal LCMV infections recently documented in transplant patients. Transmission of LCMV and LCMV-like arenavirus via solid-organ transplantation has been reported in five clusters (CDC, 2008; Fischer et al., 2006; MacNeil et al., 2012; Palacios et al., 2008). Of 17 recipients described in these clusters, 14 died of multisystem organ failure, with LCMV-associated hepatitis as a prominent feature. The surviving patient in one cluster was treated by ribavirin (an antiviral with in vitro activity against LCMV) and decrease of immunosuppression therapy (Fischer et al., 2006). Two other infected recipients survived, without receiving therapy targeted at LCMV infection (MacNeil et al., 2012). There were no clinical signs of LCMV infection or evidence of infection by PCR or serologic analysis in two donors, in three other cases results of laboratory testing indicated that the donors could be the source of LCMV infection. The source of infection in one of the donors was identified definitively as a pet hamster, but the other sources remain unknown. LCMV infections were confirmed in four clusters by means of viral culture, electron microscopy, RT-PCR, and specific immunohistochemical and serologic tests (CDC, 2008; Fischer et al., 2006; MacNeil et al., 2012). In one cluster, a new arenavirus was first detected through unbiased high-throughput sequencing. Thereafter, the infection was confirmed by other methods (Palacios et al., 2008). In these cases, CNS abnormalities occurred but were dominated by VHF-like systemic disease. Thus, the pathogenesis of these syndromes appeared to be dependent on sustained viremia and not on the T-cell immune response to virus in tissues, as are meningeal syndromes in mice and humans. Indeed, immunosuppression is not protective in these cases but rather predisposes humans to fatal disease.

In contrast to adult infection in which severe disease is rare, prenatal LCMV infection in humans is often associated with a severe negative impact on the health of the fetus. 
Infection with LCMV during the first trimester of pregnancy is associated with an increased risk of spontaneous abortion (Barton and Mets, 1999; Barton et al., 2002). Infection during the second and third trimester has been linked to congenital intrauterine infection characterized by hydrocephalus, macrocephaly or microcephaly, psychomotor retardation, periventricular calcifications, gyral dysplasia, cerebellar hypoplasia, focal cerebral destruction, visual loss, and chorioretinis (Barton and Mets, 1999; Barton et al., 2002; Bonthius and Perlman, 2007; Jamieson et al., 2006). Transplacental infection of the fetus is thought to occur during maternal viremia in mid to late pregnancy (Kunz and de la Torre, 2008). The first recognized case of congenital infection with LCMV was reported in England in 1955 (Komrower et al., 1955). In the decades that followed, multiple cases of congenital LCMV infection were reported worldwide (Bonthius and Perlman, 2007; Jamieson et al., 2006). Only half of the cases were associated with symptomatic illness of the mother. Rodent exposure of the pregnant woman was noted in more than a third of the cases. Hydrocephalus and chorioretinis were diagnosed in the majority of children with congenital LCMV infection (Greenhow and Weintrub, 2003; Mets et al., 2000; Schulte et al., 2006). Other reported ophthalmologic findings include chorioretinal scars, optic atrophy, nystagmus, esotropia, microphthalmia, and cataracts (Jamieson et al., 2006). A case of vertical transmission, which became first appeared as fetal hydrops was also recently reported. Analysis of the viral genome led to the discovery of a new strain called LCMV-LE (Meritet et al., 2009). Approximately 35\% of infants die from complications of congenital LCMV. Among survivors, two thirds suffered from long-term neurological impairments including microcephaly, mental retardation, seizures, and visual impairment. The true prevalence of congenital LCMV infection is unknown partly because it mimics congenital toxoplasmosis or cytomegalovirus infection (Wright et al., 1997). Evidence supports the hypothesis that congenital LCMV infection might be much more common than recognized. LCMV should therefore be included in the differential diagnosis of every congenital human infection in which the classical TORCH pathogens (toxoplasmosis, rubella, cytomegalovirus, and herpes virus) have been excluded. Because there is no treatment for this infection, prevention becomes the basis of intervention. Pregnant women should be informed to avoid all contact with rodents.

\section{LCMV MX strain and our contribution to the knowledge of LCMV}

The history of MX strain of LCMV began when Zavada and colleagues observed that MaTu cells (derived from a human mammary carcinoma) contained an "unconventional" transmissible agent that did not induce cytopathic effect and did not form virions visible by electron microscopy. The MaTu agent can be transmitted only by cell-to-cell contact, but not by filtered media from infected cells (Zavada et al., 1972, 1974). It has an extremely restricted host range and is transmissible to HeLa and HEF cells, but not to various human tumor cell lines or animal cell cultures. Notably, some human and animal sera contained antibodies that precipitated from MaTu cell extract, a single protein of 58 $\mathrm{kDa}$ (Zavada and Zavadova, 1991).

Monoclonal antibodies prepared against MaTu antigen recognize two different proteins involved in the MaTu phenomenon. An endogenous cellular protein, MN, localized at the plasma membrane and an exogenous, transmissible agent, MX, which is related to $58 \mathrm{kDa}$ cytoplasmic protein that can be precipitated by human and animal sera (Pastorekova et al., 1992). In order to elucidate the molecular character of the MaTu-MX agent, $58 \mathrm{kDa}$ MX-related protein was purified from MaTu cells and analyzed by amino-terminal sequencing. Comparison of partial amino acid sequences with the protein databases revealed that MX protein is closely related to NP of LCMV. Northern blotting analysis also confirmed the presence of LCMV RNA in MaTu cells. Moreover, a cDNA encoding LCMV MX nucleoprotein was cloned and subsequently sequenced. Comparative analysis with the known NP sequences from the other LCMV strains and arenaviruses provided additional evidence that MX agent is in fact a new strain of LCMV (Reiserova et al., 1999). Further determination of the primary structure of ZP gene (Gibadulinova et al., 1998), as well as GP and L genes respectively, confirmed that MX represents a distinct strain of LCMV (Tomaskova et al., 2008).

The second protein involved in the MaTu phenomenon, an endogenous protein, $\mathrm{MN}$, has become a subject of intense investigation due to its strong association with human carcinomas (Zavada et al., 1993). It was identified as the transmembrane carbonic anhydrase isoform IX (CAIX) (Opavsky et al., 1996; Pastorek et al., 1994), the expression of which is predominantly associated with hypoxic tumors of poor prognosis (Wykoff et al., 2000). Previous evidence suggested that LCMV MX might induce the expression of CA IX (Zavada and Zavadova, 1991). If this were true then the virus infection would represent a potential risk factor for patients with tumors. Therefore, we decided to verify the relationship between LCMV MX and CA IX. Our results clearly showed that expression of CA IX is independent of LCMV MX and that the virus itself does not influence the CA IX level in HeLa cells (Labudova et al., 2006). However, in view of the most recent data mentioned below, it is quite possible that the link (albeit indirect) between CA IX and LCMV does 
exist (Tomaskova et al, 2010) and that CA IX indicates a physiological situation that leads to the reactivation of persistent LCMV infection.

As previously mentioned, MX strain of LCMV spreads via cell-to-cell contact and cannot be transferred to non-infected cells by filtered medium that shows on an absence of mature extracellular virions. Consequently, the spread of persistent, cell-associated LCMV infection in culture must depend largely on intracellular connections that mediate continuity between neighboring cells. Using a proteomic approach, we identified keratin 1 (K1), an intermediate filament network component, as a binding partner of the viral NP. Although chemical disruption of keratin network resulted in a reduced spread of LCMV MX in HeLa cells, K1 disassembly was considerably lower in LCMV-infected cells compared to non-infected counterparts indicating that NP can stabilize keratin network and thereby support the integrity of cytoskeleton. Moreover, an increased formation of desmosomes and stronger cell-cell adhesion were also observed in the presence of NP. Since similar effects were observed in HeLa cells persistently infected with LCMV strain Armstrong, our findings suggest that the keratin network is important for the intercellular transmission of persistent LCMV infection in epithelial cells and show that the virus can actively facilitate its own intercellular spread through the interaction between the viral nucleoprotein and keratin 1 and stimulation of cell-cell contacts (Labudova et al., 2009).

The physiological context of virus-infected cells can markedly affect multiplication and spread of the virus progeny. During persistent infection, the virus exploits the host cell without disturbing its vital functions. However, microenvironmental hypoxia can disrupt this delicate balance and escalate virus pathogenesis. We demonstrated that exposure of cells persistently infected with LCMV MX to chronic hypoxia (monitored via detection of CA IX as an intrinsic marker of hypoxia) resulted in increased expression of all virus genes in hypoxia inducible factor-dependent manner. Hypoxic transactivation was also accompanied by the production of infectious virus particles that were released to the medium as is typical of acute or productive chronic infections. Notably, we provided the first evidence of a hypoxia-induced "reactivation" and spread of a virus with an RNA genome, which replicates in the cytoplasm in a persistent mode without disrupting cell integrity (Tomaskova et al., 2011).

We propose that this might represent a mechanism for altered virus pathogenesis in vivo in physiological and/ or pathological situations that include hypoxia and might provide an explanation for associated complications with unknown etiology. Thus, these findings represent a basis for future rational studies of the role of LCMV in human diseases linked with hypoxia.
Acknowledgements. This work was supported by the grant from the Scientific Grant Agency of Ministry of Education of the Slovak Republic and Slovak Academy of Sciences (VEGA 2/0128/11) and by the Research \& Development Operational Program funded by the ERDF (ITMS 26240120027).

\section{References}

Ackermann R (1973), In F. Lehmenn-Grube (Ed.): Lymphocytic Choriomeningitis Virus and Other Arenaviruses. Springer-Verlag, Berlin, pp. 233-237. http://dx.doi. org/10.1007/978-3-642-65681-1_21

Armstrong C, Lillie RD, Publ. Health Rep. 49, 1019-1027, 1934. http://dx.doi.org/10.2307/4581290

Barber DL, Wherry EJ, Masopust D, Zhu B, Allison JP, Sharpe AH, Freeman GJ, Ahmed R, Nature 439, 682-687, 2006. http:// dx.doi.org/10.1038/nature04444

Barton LL, Mets MB, Pediatr. Infect. Dis. J. 18, 540-541, 1999. http:// dx.doi.org/10.1097/00006454-199906000-00013

Barton LL, Mets MB, Beauchamp CL, Am. J. Obstet. Gynecol. 187, 1715-1716, 2002. http://dx.doi.org/10.1067/ mob.2002.126297

Beyer WR, Popplau D, Garten W, von Laer D, Lenz O, J. Virol. 77, 2866-2872, 2003. http://dx.doi.org/10.1128/ JVI.77.5.2866-2872.2003

Blackburn SD, Shin H, Haining WN, Zou T, Workman CJ, Polley A, Betts MR, Freeman GJ, Vignali DA, Wherry EJ, Nat. Immunol. 10, 29-37, 2009. http://dx.doi.org/10.1038/ni.1679

Boni C, Fisicaro P, Valdatta C, Amadei B, Di Vincenzo P, Giuberti T, Laccabue D, Zerbini A, Cavalli A, Missale G, Bertoletti A, Ferrari C, J. Virol. 81, 4215-4225, 2007. http://dx.doi. org/10.1128/JVI.02844-06

Bonthius DJ, Perlman S, PLoS Pathog. 3, 149, 2007. http://dx.doi. org/10.1371/journal.ppat.0030149

Borrow P, Oldstone MBA, Virology 198, 1-9, 1994. http://dx.doi. org/10.1006/viro.1994.1001

Borrow P, Oldstone MBA (1997), In Nathanson N, Ahmed R, onzalez-Scarano F, Griffin DE, Holmes KV, Murphy FA, Robinson HL (Ed.): Viral Pathogenesis. Lippincott-Raven, Philadelphia, pp. 593-627, 1997.

Brooks DG, Trifilo MJ, Edelmann KH, Teyton L, McGavern DB, Oldstone MBA, Nat. Med. 12, 1301-1309, 2006. http:// dx.doi.org/10.1038/nm1492

Buchmeier MJ, de La Torre JC, Peters CJ, In Knipe DM, Howley PM (Ed.): Fields Virology Vol. II. Lippincott Williams \& Wilkins, Philadelphia, pp. 1793-1826, 2007.

Buchmeier MJ, Zajac AJ, In Ahmed R, Chen ISY (Ed.): Persistent Viral Infections. John Wiley \& Sons, Chichester, West Sussex, pp. 575-605, 1999.

Burri DJ, Palma JR, Kunz S, Pasquato A, Viruses 4, 2162-2181, 2012. http://dx.doi.org/10.3390/v4102162

Cao W, Henry MD, Borrow P, Yamada H, Elder JH, Ravkov EV, Nichol ST, Compans RW, Campbell KP, Oldstone MB, Science 282, 2079-2081, 1998. http://dx.doi.org/10.1126/ science.282.5396.2079 
Capul AA, Perez M, Burke E, Kunz S, Buchmeier MJ, de la Torre JC, J. Virol. 81, 9451-9460, 2007. http://dx.doi.org/10.1128/ JVI.00499-07

CDC, MMWR Morb. Mortal. Wkly Rep. 54, 537-539, 2005.

CDC, MMWR Morb. Mortal. Wkly Rep. 57, 799-801, 2008.

Clegg JC, Curr. Top. Microbiol. Immunol. 262, 1-24, 2002. http:// dx.doi.org/10.1007/978-3-642-56029-3 1

Di Simone C, Buchmeier, MJ, Virology 209, 3-9, 1995. http://dx.doi. org/10.1006/viro.1995.1225

Di Simone C, Zandonatti MA, Buchmeier MJ, Virology 198, 455465, 1994. http://dx.doi.org/10.1006/viro.1994.1057

Dobec M, Dzelalija B, Punda-Polic V, Zoric I, J. Med. Virol. 78, 1643-1647, 2006. http://dx.doi.org/10.1002/jmv.20749

Dykewicz CA, Dato VM, Fisher-Hoch SP, Howarth MV, PerezOronoz GI, Ostroff SM, Gary H Jr., Schonberger LB, McCormick JB, JAMA 267, 1349-1353, 1992. http://dx.doi. org/10.1001/jama.1992.03480100055030

Eichler R, Lenz O, Strecker T, Eickmann M, Klenk HD, Garten W, J. Biol. Chem. 279, 12293-12299, 2004. http://dx.doi. org/10.1074/jbc.M312975200

Eichler R, Lenz O, Strecker T, Garten W, FEBS Lett. 538, 203-206, 2003. http://dx.doi.org/10.1016/S0014-5793(03)00160-1

Ejrnaes M, Filippi CM, Martinic MM, Ling EM, Togher LM, Crotty S, von Herrath MG, J. Exp. Med. 203, 2461-2472, 2006. http://dx.doi.org/10.1084/jem.20061462

Emonet S, Retornaz K, Gonzalez JP, de Lamballerie X, Charrel RN, Emerg. Infect. Dis. 13, 472-475, 2007. http://dx.doi. org/10.3201/eid1303.061141

Eschli B, Quirin K, Wepf A, Weber J, Zinkernagel R, Hengartner H, J. Virol. 80, 5897-5907, 2006. http://dx.doi.org/10.1128/ JVI.00008-06

Fischer SA, Graham MB, Kuehnert MJ, Kotton CN, Srinivasan A, Marty FM, Comer JA, Guarner J, Paddock CD, DeMeo DL, Shieh WJ, Erickson BR, Bandy U, DeMaria A Jr., Davis JP, Delmonico FL, Pavlin B, Likos A, Vincent MJ, Sealy TK, Goldsmith CS, Jernigan DB, Rollin PE, Packard MM, Patel M, Rowland C, Helfand RF, Nichol ST, Fishman JA, Ksiazek T, Zaki SR, N. Engl. J. Med. 354, 2235-2249, 2006. http://dx.doi.org/10.1056/NEJMoa053240

Foster ES, Signs KA, Marks DR, Kapoor H, Casey M, Stobierski MG, Walker ED, Emerg. Infect. Dis. 12, 851-853, 2006. http://dx.doi.org/10.3201/eid1205.050794

Francis SJ, Southern PJ, J. Gen. Virol. 69, 1893-902, 1988. http:// dx.doi.org/10.1099/0022-1317-69-8-1893

Freed EO, J. Virol. 76, 4679-4687, 2002. http://dx.doi.org/10.1128/ JVI.76.10.4679-4687.2002

Gibadulinova A, Zelnik V, Reiserova L, Zavodska E, Zatovicova M, Ciampor F, Pastorekova S, Pastorek J, Acta Virol. 42, 369-374, 1998.

Greenhow TL, Weintrub PS, Pediatr. Infect. Dis . J. 22, 1099, 1111 1112, 2003.

Gregg MB, Bull. WHO 52, 549-553, 1975.

Horton J, Hotchin JE, Olson KB, Davies JN, Cancer Res. 31, 10661068, 1971.

Hotchin J, Sikora E, Kinch W, Hinman A, Woodall J, Science 185, 1173-1174, 1974. http://dx.doi.org/10.1126/science.185.4157.1173
Charrel RN, de Lamballerie X, Emonet S, Curr. Opin. Microbiol. 11, 362-368, 2008. http://dx.doi.org/10.1016/j. mib.2008.06.001

Childs JE, Glass GE, Korch GW, Ksiazek TG, Leduc JW, Am. J. Trop. Med. Hyg. 47, 27-34, 1992.

Childs JE, Glass GE, Ksiazek TG, Rossi CA, Oro JG, Leduc JW, Am. J. Trop. Med. Hyg. 44, 117-121, 1991.

Childs JE, Peters CJ, In Salvato MS (Ed.): The Arenaviridae. Plenum Press, New York, pp. 331-384, 1993. http://dx.doi org/10.1007/978-1-4615-3028-2 19

Jamieson DJ, Kourtis AP, Bell M, Rasmussen SA, Am. J. Obstet. Gynecol. 194, 1532-1536, 2006. http://dx.doi. org/10.1016/j.ajog.2005.11.040

Jin HT, Anderson AC, Tan WG, West EE, Ha SJ, Araki K, Freeman GJ, Kuchroo VK, Ahmed R, Proc. Natl. Acad. Sci. USA 107, 14733-14738, 2010. http://dx.doi.org/10.1073/ pnas. 1009731107

Kallio-Kokko H, Laakkonen J, Rizzoli A, Tagliapietra V, Cattadori I, Perkins SE, Hudson PJ, Cristofolini A, Versini W, Vapalahti O, Vaheri A, Henttonen H, Epidemiol. Infect. 134, 830-836, 2006. http://dx.doi.org/10.1017/S0950268805005431

Komrower GM, Williams BL, Stones PB, Lancet 268, 697-698, 1955. http://dx.doi.org/10.1016/S0140-6736(55)91066-7

Kunz S, Virology 387, 245-249, 2009. http://dx.doi.org/10.1016/j. virol.2009.02.042

Kunz S, de la Torre JC, In Shoshkes Reiss C (Ed.): Neurotropic Viral Infections. Cambridge University Press, New York, pp. 75-93, 2008. http://dx.doi.org/10.1017/ CBO9780511541728.008

Kunz S, Edelmann KH, de la Torre JC, Gorney R, Oldstone MB, Virology 314, 168-78, 2003. http://dx.doi.org/10.1016/ $\underline{\text { S0042-6822(03)00421-5 }}$

Labudova M, Tomaskova J, Kaluzova M, Pastorek J, Pastorekova S, Acta Virol. 50, 53-58, 2006.

Labudova M, Tomaskova J, Skultety L, Pastorek J, Pastorekova S, J. Virol. 83, 7842-7849, 2009. http://dx.doi.org/10.1128/ JVI.00309-09

Lee KJ, Novella IS, Teng MN, Oldstone MB, and de La Torre JC, J. Virol. 74, 3470-3477, 2000. http://dx.doi.org/10.1128/ JVI.74.8.3470-3477.2000

Lledo L, Gegundez MI, Saz JV, Bahamontes N, Beltran M, J. Med. Virol. 70, 273-275, 2003. http://dx.doi.org/10.1002/ imv.10389

MacNeil A, Stroher U, Farnon E, Campbell S, Cannon D, Paddock CD, Drew CP, Kuehnert M, Knust B, Gruenenfelder R, Zaki SR, Rollin PE, Nichol ST, Emerg. Infect. Dis. 18, 1256-1262, 2012. http://dx.doi.org/10.3201/ eid1808.120212

Marrie TJ, Saron MF, Am. J. Trop. Med. Hyg. 58, 47-49, 1998.

McGavern DB, J. Mol. Cell. Biol. 2, 8-10, 2009. http://dx.doi. org/10.1093/jmcb/mip021

Meritet JF, Krivine A, Lewin F, Poissonnier MH, Poizat R, Loget P, Rozenberg F, Lebon P, Prenat. Diagn. 29, 626-627, 2009. http://dx.doi.org/10.1002/pd.2240

Mets MB, Barton LL, Khan AS, Ksiazek TG, Am. J. Ophthalmol. 130, 209-215, 2000. http://dx.doi.org/10.1016/S0002$\underline{9394(00) 00570-5}$

Meyer BJ, Southern PJ, J. Virol. 67, 2621-2627, 1993. 
Meyer BJ, Southern PJ, J. Virol. 68, 7659-7664, 1994.

Meyer BJ, Southern PJ, J. Virol. 71, 6757-6764, 1997.

Morin B, Coutard B, Lelke M, Ferron F, Kerber R, Jamal S, Frangeul A, Baronti C, Charrel R, de Lamballerie X, Vonrhein C, Lescar J, Bricogne G, Gunther S, Canard B, PLoS Pathog. 6, e1001038, 2010. http://dx.doi.org/10.1371/journal.ppat.1001038

Moskophidis D, Lechner F, Pircher H, Zinkernagel RM, Nature 362, 758-761, 1993. http://dx.doi.org/10.1038/362758a0

Mueller SN, Ahmed R, Proc. Natl. Acad. Sci. USA 106, 8623-8628, 2009. http://dx.doi.org/10.1073/pnas.0809818106

Neuman BW, Adair BD, Burns JW, Milligan RA, Buchmeier MJ, Yeager M, J. Virol. 79, 3822-3830, 2005. http://dx.doi. org/10.1128/JVI.79.6.3822-3830.2005

Ng CT, Sullivan BM, Oldstone MB, Curr. Opin. Virol. 1, 160-166, 2011. http://dx.doi.org/10.1016/j.coviro.2011.05.006

Oldstone MB, Curr Top Microbiol. Immunol. 263, 83-117, 2002. http://dx.doi.org/10.1007/978-3-642-56055-2 6

Oldstone MB, Virology 344, 111-118, 2006. http://dx.doi. org/10.1016/j.virol.2005.09.028

Oldstone MB, PLoS Pathog. 5, e1000523, 2009. http://dx.doi. org/10.1371/journal.ppat.1000523

Oldstone MB, Campbell KP, Virology 411, 170-179, 2011. http:// dx.doi.org/10.1016/j.virol.2010.11.023

Opavsky R, Pastorekova S, Zelnik V, Gibadulinova A, Stanbridge EJ, Zavada J, Kettmann R, Pastorek J, Genomics 33, 480-487, 1996. http://dx.doi.org/10.1006/geno.1996.0223

Palacios G, Druce J, Du L, Tran T, Birch C, Briese T, Conlan S, Quan PL, Hui J, Marshall J, Simons JF, Egholm M, Paddock CD, Shieh WJ, Goldsmith CS, Zaki SR, Catton M, Lipkin WI, Nl Engll Jl Medl 358, 991-998, 2008. http:// dx.doi.org/10.1056/NEJMoa073785

Park JY, Peters CJ, Rollin PE, Ksiazek TG, Katholi CR, Waites KB, Gray B, Maetz HM, Stephensen CB, Am. J. Trop. Med. Hyg. 57, 37-41, 1997.

Pasqual G, Rojek JM, Masin M, Chatton JY, Kunz S, PLoS Pathog. 7, e1002232, 2011. http://dx.doi.org/10.1371/journal. ppat.1002232

Pastorek J, Pastorekova S, Callebaut I, Mornon JP, Zelnik V, Opavsky R, Zatovicova M, Liao S, Portetelle D, Stanbridge EJ, et al., Oncogene 9, 2877-2888, 1994.

Pastorekova S, Zavadova Z, Kostal M, Babusikova O, Zavada J, Virology 187, 620-626, 1992. http://dx.doi.org/10.1016/00426822(92)90464-Z

Perez M, Craven RC, de la Torre JC, Proc. Natl. Acad. Sci. USA 100, 12978-12983, 2003. http://dx.doi.org/10.1073/ pnas. 2133782100

Perez M, de la Torre JC, J. Virol. 77, 1184-1194, 2003. http://dx.doi. org/10.1128/JVI.77.2.1184-1194.2003

Perez M, Greenwald DL, de la Torre JC, J. Virol. 78, 11443-11448, 2004. http://dx.doi.org/10.1128/JVI.78.20.11443-11448.2004

Qi X, Lan S, Wang W, Schelde LM, Dong H, Wallat GD, Ly H, Liang Y, Dong C, Nature 468, 779-783, 2010. http://dx.doi. org/10.1038/nature09605

Quirin K, Eschli B, Scheu I, Poort L, Kartenbeck J, Helenius A, Virology 378, 21-33, 2008. http://dx.doi.org/10.1016/j. virol.2008.04.046

Reiserova L, Kaluzova M, Kaluz S, Willis AC, Zavada J, Zavodska E, Zavadova Z, Ciampor F, Pastorek J, Pastorekova S,
Virology 257, 73-83, 1999. http://dx.doi.org/10.1006/ viro. 1999.9638

Riera L, Castillo E, Del Carmen Saavedra M, Priotto J, Sottosanti J, Polop J, Ambrosio AM, J. Med. Virol. 76, 285-289, 2005. http://dx.doi.org/10.1002/jmv.20357

Richter K, Agnellini P, Oxenius A, Int. Immunol. 22, 13-23, 2010. http://dx.doi.org/10.1093/intimm/dxp107

Rivers TM, Scott TFM, Science 81, 439-440, 1935. http://dx.doi. org/10.1126/science.81.2105.439-a

Rojek JM, Perez M, Kunz S, J. Virol. 82, 1505-1517, 2008. http:// dx.doi.org/10.1128/JVI.01331-07

Rowe WP, Murphy FA, Bergold GH, Casals J, Hotchin J, Johnson KM, Lehmann-Grube F, Mims CA, Traub E, Webb PA, J. Virol. 5, 651-652, 1970.

Saunders AA, Ting JP, Meisner J, Neuman BW, Perez M, de la Torre JC, Buchmeier MJ, J. Virol. 81, 5649-5657, 2007. http:// dx.doi.org/10.1128/JVI.02759-06

Schulte DJ, Comer JA, Erickson BR, Rollin PE, Nichol ST, Ksiazek TG, Lehman D, Pediatr. Infect. Dis. J 25, 560-562, 2006. http://dx.doi.org/10.1097/01. inf.0000219409.57917.35

Stephensen CB, Blount SR, Lanford RE, Holmes KV, Montali RJ, Fleenor ME, Shaw JF, J. Med. Virol. 38, 27-31, 1992.http:// dx.doi.org/10.1002/jmv.1890380107

Strecker T, Eichler R, Meulen J, Weissenhorn W, Dieter Klenk H, Garten W, Lenz O, J. Virol. 77, 10700-10705, 2003. http://dx.doi.org/10.1128/JVI.77.19.1070010705.2003

Sullivan BM, Emonet SF, Welch MJ, Lee AM, Campbell KP, de la Torre JC, Oldstone MB, Proc. Natl. Acad. Sci. USA 108, 2969-2974, 2011. http://dx.doi.org/10.1073/ pnas. 1019304108

Tomaskova J, Labudova M, Kopacek J, Pastorekova S, Pastorek J, Virus Genes 37, 31-38, 2008. http://dx.doi.org/10.1007/ s11262-008-0240-2

Tomaskova J, Oveckova I, Labudova M, Lukacikova L, Laposova K, Kopacek J, Pastorekova S, Pastorek J, J. Virol. 85, 13069-13076, 2011. http://dx.doi.org/10.1128/ JVI.00829-11

Tortorici MA, Albarino CG, Posik DM, Ghiringhelli PD, Lozano ME, Rivera Pomar R, Romanowski V, Virus Res. 73, 41-55, 2001. http://dx.doi.org/10.1016/S0168-1702(00)00222-7

Traub E, J. Exp. Med. 64, 183-200, 1936. http://dx.doi.org/10.1084/ jem.64.2.183

Urbani S, Amadei B, Tola D, Massari M, Schivazappa S, Missale G, Ferrari C, J. Virol. 80, 11398-11403, 2006. http://dx.doi. org/10.1128/JVI.01177-06

Welsh R, In Mahy BWJ, van Regenmortel MHV (Ed.): Encyclopedia of Virology Academic Press Amsterdam; Boston pp. 238-243, 2008. http://dx.doi.org/10.1016/B978012374410-4.00439-8

Welsh RM, In Cunningham MW, Fujinami RS (Ed.): Effects of Microbes on the Immune System. Lippincott Williams \& Wilkins, Philadelphia, pp. 289-312, 2000.

Wilson EB, Brooks DG, Immunol. Res. 48, 3-13, 2010. http://dx.doi. org/10.1007/s12026-010-8162-1

Wright R, Johnson D, Neumann M, Ksiazek TG, Rollin P, Keech RV, Bonthius DJ, Hitchon P, Grose CF, Bell WE, Bale JF 
Jr., Pediatrics 100, E9, 1997. http://dx.doi.org/10.1542/ peds.100.1.e9

Wykoff CC, Beasley NJ, Watson PH, Turner KJ, Pastorek J, Sibtain A, Wilson GD, Turley H, Talks KL, Maxwell PH, Pugh CW, Ratcliffe PJ, Harris AL, Cancer Res. 60, 7075-7083, 2000.

Yi JS, Du M, Zajac AJ, Science 324, 1572-1576, 2009. http://dx.doi. org/10.1126/science. 1175194

York J, Nunberg JH, J. Virol. 80, 7775-7780, 2006. http://dx.doi. org/10.1128/JVI.00642-06

York J, Romanowski V, Lu M, Nunberg JH, J. Virol. 78, 10783 10792, 2004. http://dx.doi.org/10.1128/JVI.78.19.10783$\underline{10792.2004}$

Zavada J, Zavadova Z, Arch. Virol. 118, 189-197, 1991. http://dx.doi. org/10.1007/BF01314029
Zavada J, Zavadova Z, Widmaier R, Bubenik J, Indrova M, Altaner C, J. Gen. Virol. 24, 327-337, 1974. http://dx.doi. org/10.1099/0022-1317-24-2-327

Zavada J, Zavadova Z, Malir A, Kocent A, Nat. New Biol. 240, 124-125, 1972.

Zavada J, Zavadova Z, Pastorekova S, Ciampor F, Pastorek J, Zelnik V, Int. J. Cancer 54, 268-274, 1993. http://dx.doi. org/10.1002/ijc.2910540218

Zinkernagel RM, Science 271, 173-178, 1996. http://dx.doi. org/10.1126/science. 271.5246 .173

Zinkernagel RM, Curr. Top. Microbiol. Immunol. 263, 1-5, 2002. http://dx.doi.org/10.1007/978-3-642-56055-2 1

Zinkernagel RM, Doherty PC, Contemp. Top. Immunobiol. 7, 179-220, 1977. http://dx.doi.org/10.1007/978-1-4684-3054-7 5 